\title{
Dylan's Judgment
}

\section{Aidan Day}

University of Aarhus

\begin{abstract}
The title of this paper refers to Dylan's preoccupation with the question of divine intervention in the world. In 2002 Mark Ford spoke of "the Apocalyptic fury that drives and holds together the dizzying poetry" of Dylan's 1981 song, "Caribbean Wind." The paper begins by paying close attention to the words of the 1985 Biograph version of "Caribbean Wind" before moving on to examine the figuring of divine Judgment in other 1980s songs such as "Jokerman" and "I and I." The overall argument of the paper is that the sense of apocalypse in these songs draws its strength primarily not from Christianity but from Dylan's specifically Jewish cultural roots. As such, the apocalyptic perspective has conditioned Dylan's work from the outset of his career. Songs from the 1960s, including "Long Time Gone," "A Hard Rain's A-Gonna Fall," and "Desolation Row," are referred to in order to demonstrate the way in which an Hebraic conviction of imminent, absolute Judgment and punishment constitutes the most consistent imaginative preoccupation of Dylan's lyrical career. It is this preoccupation, above all else, that sets a limit to understanding Dylan's work in postmodern terms. ${ }^{1}$
\end{abstract}

Keywords: Apocalypse - Judgment - profanity - religion - Christianity - Judaism - postmodernism - identity - carnival - song-poem

In 2002 Mark Ford spoke of "The Apocalyptic fury that drives and holds together the dizzying poetry" of Bob Dylan's early 1980s song "Caribbean Wind" (139). The opening three lines of the studio version of this song, recorded on 7 April 1981 and released on Biograph in 1985, read like this:

She was the rose of Sharon from paradise lost

From the city of seven hills near the place of the cross

I was playing a show in Miami in the theater of divine comedy. (1-3)

1. An earlier version of this essay was delivered as an invited paper at a conference, "A Series of Interpretations of Bob Dylan's Lyrical Works: An Academic Conference at Dartmouth College," held at the Department of English, Dartmouth College, New Hampshire, USA, on August 11-13, 2006. Quotations of Dylan's lyrics are from Bob Dylan: Lyrics 1962-2001 (London: Simon and Schuster, 2004). 
What I want to do in this article, first of all, is to tease out some of the possibilities in this dizzying initial onslaught of reference and allusion in "Caribbean Wind." I shall then raise some questions about the entire song, before moving on to set my discussion in the perspective of Dylan's work as a whole. I shall be arguing for the fundamentally religious rather than postmodern nature of Dylan's imagination throughout his career.

In the Biblical Song of Solomon (King James version) the beloved woman, the original "rose of Sharon," declares of her lover:

Let him kiss me with the kisses of his mouth ... (1.2)

A bundle of myrrh is my well-beloved unto me; he shall lie all night betwixt my breasts. (1.13)

The eroticism of the "Song of Solomon" is famous. It is also infamous. The worldliness of eroticism, troubling to the spiritually minded, is something underlined by Dylan when the speaker of "Caribbean Wind" tells us, almost immediately, that his beloved is from a fallen world: "She was the rose of Sharon from paradise lost." The expression "paradise lost" - reminding us, inevitably, of Milton - establishes the metaphysical frame within which the song is cast. That frame is hinted at again in the Dantesque "theater of divine comedy" in the third line. It is emphasized once more when, in the fourth line of the song, we hear that this Rose of Sharon was someone who had "told" the speaker "about Jesus." In other words, the sensuality that is, in part, invoked in the naming of the beloved woman as the Rose of Sharon, is being explored in the song in the context of a religious drama set between the flesh and the spirit, between the world of experience, on the one hand, and a higher realm, on the other.

This drama in any case shadows the very reference to the "Song of Solomon," since the eroticism of the Biblical book was only accommodated by Christianity on the grounds that it should be read as an allegory of the love between Christ and the soul, or between Christ and the Church, just as Judaism interpreted the book as depicting the relations between Jahweh and his people. The Rose of Sharon, looked at from a worldly perspective, may be a seriously sensuous woman; but allegorized as a type of the soul she may stand for the spiritual principle that sustains the individual in a world of $\sin$. A.S. Byatt has noted that, in the tradition of interpretation handed down by the Fathers of the Christian Church, the 


\section{"Song of Solomon" became}

an extraordinary paradox - a rich, fleshy metaphor for the divine longing that would cause the wise soul to reject the flesh and its desires. Origen's explanation [in the third century] turned on the doubleness of the Latin word, amor, love, which was used to describe carnal desire and spiritual yearning. (viii)

Dylan is interested in this paradox in "Caribbean Wind." But he is not so much concerned to enshrine the paradox as to explore the confusion at its root, a confusion that is inherent in the terms of the drama he has staged in his song. The Rose of Sharon in the song is associated, on the one hand, with having told the speaker about Jesus. Thus far she would be consonant with the Christian allegorical reading of the "Song of Solomon" as a text of spiritual import. On the other hand, the relationship between the speaker of "Caribbean Wind" and the woman who told him about Jesus was more than just a spiritual communion. Describing his beloved as the Rose of Sharon, the speaker in Dylan's song puts himself in the position of the lover in the "Song of Solomon," who addresses the Biblical Rose of Sharon in entrancedly sensuous terms, as the following extracts, taken almost at random from Chapter Four, indicate:

Thy lips are like a thread of scarlet ... (4.3)

Thy two breasts are like two young roes that are twins, which feed among the lilies (4.5)

Thou hast ravished my heart ... with ... thine eyes ... (4.9)

The relationship between the speaker in "Caribbean Wind" and his Rose of Sharon, while it may have involved a spiritual aspect, was at the same time a relationship of earthly lovers. As such, we find that there is a repeated insinuation that the relationship involved some kind of transgression. "Did we go too far?" the speaker asks in the second verse of the song, "Through the hole in the wall to where the long arm of the law cannot reach?" $(7,9)$. "Did you... / Ever meet your accusers face to face in the rain?" he asks in lines 31-32. Accused of what, exactly? The expression "meet your accusers" recalls Acts 25:16 ("It is not the manner of the Romans to deliver any man to die, before that he which is accused have the accusers face to face,"), where St. Paul is arguing the question about whether he is to be judged by the Sanhedrin or by the Romans. The speaker of Dylan's song is uneasily aware of facing some kind of indictment in respect of his relationship with the woman of the song. As a union of the human heart and flesh, the relationship seems to have carried 
with it entanglements that the speaker experiences as compromising. When he tells us of his past involvement with the woman - a past captured through Dylan's characteristic device of separating a past from a present self through picturing the past self in the third person ${ }^{2}-$ we hear that for the speaker

... her heart was a snare

And she had left him to die in there,

He was goin' down slow, just barely staying alive. (16-18)

The Rose of Sharon may have told him about Jesus, but the speaker is struggling with a sense that he may have embarked, in his relationship with her, on a spiritually entrapping, a spiritually dangerous confusion of the sacred and the profane.

There is a fiercely profane energy in the "winds" that, in the second line of the refrain to "Caribbean Wind," fan "the flames in the furnace of desire," just as there is a profane aspect to the "heat in my bed" which the speaker records in the fourth verse (20). But the profane heat in "Caribbean Wind" can be contrasted with - though it is also connected to - another kind of heat, because the song is driven above all else by an anxiety about divine judgment of profanity. The apocalyptic tendency of Dylan's imagination in "Caribbean Wind" first becomes fully explicit in the refrain. The "iron waves" in the refrain bear everything that is near to the speaker nearer to an apocalyptic fire, in the same way as fire dominates the scene in the apocalyptic imagining of the second refrain in another 1981 song, "The Groom's Still Waiting at the Altar":

West of the Jordan, east of the Rock of Gibraltar

I see the burning of the stage

Curtain rising on a new age ...

In the third and fourth lines of the refrain to "Caribbean Wind" we hear of the

... ships of liberty on them iron waves so bold and free,

Bringing everything that's near to me nearer to the fire.

The burning in "The Groom's Still Waiting at the Altar" and the con- 
cluding "fire" in the "Caribbean Wind" refrain are, in part, to be identified with the "fire" of Judgment in Revelation (18.8). This is the fire that will consume the "iniquities" of Rome conceived as the satanically driven harlot city, "Babylon" (Revelation 18.5, 2). The "burning" in the "Groom" and the "fire" in "Caribbean Wind" are types of the "lake of fire" in Revelation (20.10), into which Satan and his allies are cast at the Last Judgment. This apocalyptic note is actually introduced, covertly, in the second line of "Caribbean Wind." The contrast between the drives of "the devil, the world, and the flesh," to quote the English Book of Common Prayer, and the powers of a higher, spiritual dispensation, is reiterated in that line through the juxtaposition of the "city of seven hills" with "the place of the cross" - Calvary or Golgotha. The "city of seven hills" is Rome, above all others. In Dylan's line, Rome is juxtaposed, in an impossible literal geography, with the place of the cross in a manner that parallels the contrast that is laid out in Revelation between the depraved power of Imperial Rome, Babylon, and a principle of spiritual renovation. It is the principle of renovation that, in Revelation, drives the assumption into the Millenium and thereafter into the "new heaven and new earth" (Revelation 21.1-2) of those whom Dylan calls - in "Ring them Bells," from 1989's Oh Mercy - the "chosen few" (27), and whom Revelation calls the "saints" (20.9), the righteous few who have not submitted to Rome / Babylon's heinous influence.

Yet it is not just an anxiety about a profane transgression that motivates the speaker's reflections on his Rose of Sharon. There is more. Perhaps the spiritual message concerning Jesus was itself not pure. In the first place, the statements that "her heart was a snare / And she had left him to die in there" (16-17) are themselves strong accusations. More important is line 10 of the song, when the speaker asks: "Could I [have] been used and played as a pawn?" Had this woman, all the time she was proselytizing about Jesus, actually been playing the speaker as a pawn? Were the speaker's response to the Christian message of his Rose of Sharon - perhaps the messenger herself, even the message itself - things that were compromised, their nature qualified, at least, not simply by matters of the flesh but also by the fact that, as the speaker now recognizes, he might have been the object of use and exploitation? Read like this, the lines, the song as a whole, amount to an implied negative criticism on Dylan's part of his own espousal of an acute evangelical Christianity at the turn of the 
1970 s into the 1980 s. The song might then signify a distancing of the self from that high Christian moment. Bryan Cheyette has noted Allen Ginsberg's observation that "one of the key indications that Dylan's Christian orthodoxy was beginning to wane by the time of Shot of Love" in 1981 "is that this album contains the heartfelt lament for Lenny Bruce," a Jew whose satire "could not have been more outrageously Jewish" (Cheyette 248-49). It is in this context that the last line of the last verse of "Caribbean Wind" carries a special force. After lines, in the body of the verse, which present a sense of the imminence of apocalypse -

Every new messenger bringing evil report

About armics on the march and time that is short

And famines and earthquakes and trainwrecks and the tearing down of the wall-

the speaker concludes with:

I can hear my ancestors calling from the land far beyond. $(28-30,36)$

Ancestors calling - from past, present and future. It is not that Dylan forsakes a spiritual perspective in "Caribbean Wind," but rather that he is signaling withdrawal from extreme Christian evangelism and some order of return to his specifically Jewish spiritual grounding.

The waning of Dylan's Christian orthodoxy was to be signaled again in his 1983 song "Jokerman." The figure of the Jokerman, described in the first line of the song as "Standing on the waters casting your bread," is in part a figure of Christ. But there is a problem with the Christ envisaged in this song. In the last verse, the Jokerman is pictured in relation to a power of evil:

It's a shadowy world, skies are slippery grey,

A woman just gave birth to a prince today and dressed him in scarlet.

He'1l put the pricst in his pocket, put the blade to the heat,

Take the motherless children off the street

And place them at the feet of a harlot.

Oh, Jokerman, you know what he wants,

Oh, Jokerman, you don't show any response. (31-37)

Putting blades to the heat and placing motherless children at the feet of a harlot gives a pretty good idea of where the prince is headed. The identification of evil power in terms of a "prince" in any case recalls Dylan's line in his 1979 song "Trouble in Mind," - "Here comes Satan, prince of 
the power of the air" (9) - which echoes St. Paul's description in Ephesians 2.2 of Satan as the "prince of the power of the air." But the lack of response to the prince on the part of the Christ figure in "Jokerman" suggests, from the point of view of the speaker of the song, a crisis of confidence in the adequacy of that figure as an agent of salvation. The Satanic "prince" is embedded in this concluding verse of "Jokerman" within a series of reminders of the Book of Revelation. The image of the woman, dressing in scarlet a prince who will place motherless children at the feet of a harlot, has elements which recall Revelation 17.3-5:

So he carried me away in the spirit into the wilderness: and I saw a woman sit upon a scarlet coloured beast, full of names of hlasphemy ... (17.3)

And the woman was arrayed in purple and scarlet colour ... (17.4)

And upon her forchead was a name written, MYSTERY, BABYLON THE GREAT, THE MOTHER OF HARLOTS AND ABOMINATIONS OF THE EARTH. (17.5)

In Revelation, Satan is at last overthrown by God in the person of Christ. In "Jokerman," however, the specifically Christian cycle of Revelation cannot be completed by virtue of the insufficiency of the Christ figure's lack of response to Satan's challenge. There are intimations of apocalypse in the song without the specific Christian promise of potential redemption.

The Apocalypse is, after all, not just part of the New Testament biblical tradition. It is a part of the Old Testament as well. The visions of Revelation have antecedents not just in late apocalyptic books like Daniel, but in prophetic books like Isaiah. In The Apocalyptic Imagination: An Introduction to the Jewish Matrix of Christianity, John J. Collins observes that "the basic configuration of apocalyptic thought can already be found in the late prophetic texts" (19). The Revelation visions with their characteristic imagery, their foretelling of cosmic Judgment, their picturing of the survival of a remnant of people who remain true to God, are anticipated in Isaiah, a book to which Dylan has frequently alluded, from the 1968 "All along the Watchtower" to the 1983 "I and I." In Isaiah, Jahweh's judgment on the failings of his people is to come by fire: "the Lord will come with fire ... to render his anger with fury, and his rebuke with flames of fire" (66.15). The selected few who escape this fury will be called "holy": 
[I]t shall come to pass, that he that is left in Zion ... shall be called holy... (4.3)

When the Lord ... shall have purged the blood of Jerusalem from the midst thereof by the spirit of judgment, and by the spirit of burning. (4.4)

The spirit of judgment. The spirit of burning. Turning to the ancestors in "Caribbean Wind" does not involve any relinquishing of an urgent sense of an ending. But it marks a shift towards a more Old Testament understanding of divine judgment, unleavened by the Christian idea of divine forgiveness. It is not that the Old Testament Jahweh does not allow a just few, a remnant, to escape his wrath - from Noah's escape from the Flood visited upon human kind in Genesis to the "holy" who will survive the "flames of fire" in Isaiah. But what Bryan Cheyette has termed "the vengeful law of the Hebrew Bible" (250) is less yielding than the Christian. If men broke the Covenant with the God of the Old Testament, there was no way back and divine retribution was unavoidable. Under the redemptive dispensation of the Covenant of the New Testament, it was possible to find a way back after transgression. Dylan's sense of impending judgment does not decrease after the three Christian albums of 1979-81 have been left behind. But that sense of the coming end is conceived in harsher terms. The possible relief offered by the Christian reading of divine Judgment is less clearly felt. Those of Dylan's songs after the Christian phase that treat of the final end tend to be characterized by a subjective dread of being found lacking and of being sentenced by an inflexible, unrelenting absolute. It is this note that is struck in another song from the 1983 Infidels, "I and I." The foundation of "I and I," stated in the eleventh and twelfth lines of the song, is the sublimely terrible equity of Mosaic Law:

Took a stranger to teach me, to look into justice's beautiful face And to sec an eye for an eye and a tooth for a tooth.

"I and I" is preoccupied with the relation of the individual to the God who imposes such retaliatory, retributive equity. The refrain, like the title of song, turns on the relation between the individual and the God of the Old Testament. In a 1985 interview Dylan observed:

Sometimes the "you" in my songs is me talking to me. Other times I can be talking to somebody else ... The "I," like in "I and I," also changes. It could be I, or it could be the 
"I" who created me. (Cohen 223)

Dylan's point explicates something of the refrain of "I and I":

I and I

In creation where one's nature neither honors nor forgives.

I and I

One says to the other, no man sees my face and lives.

In the last of these four lines of the refrain, one of the "I"-s is the Mosaic God of Exodus, who declares "I AM THAT I AM" (3.14). In Dylan's line the total otherness from man of this God is defined through an echo of the statement made by God to Moses in Exodus 33.20: "Thou canst not see my face: for there shall no man see me, and live." The "other" who is spoken to in this line is the human self who experiences the absolute unapproachability, the absolute overpoweringness, of a God so conceived.

In the second line of the refrain, the mortal "I" and the divine identity may appear to fuse in the "one" of "one's nature." But the reconciliation is only apparent. Neither identity may be capable of real esteem or pity. But they are incapable because of very different reasons - the incapacity of the one because of mortal unregeneracy, the incapacity of the divine other because of its absolute self-sufficiency. Either way, there is no humanly meaningful traffic between the mortal and the divine. The relation seems symmetrically reflexive - "I and I" - but it is simultaneously discordant. The two identities in the lines of Dylan's refrain, that of the mortal self and that of the Godhead, are caught in a brutal economy. The absolute has no human face and the human is condemned to a dread of the sublime for its lack of concession to the human.

It is this lack of concession which gives rise to the psychological and emotional tension in the first two lines of the last verse of "I and I," as the speaker describes a kind of final undertaking:

Noontime, and I'm still pushin' myself along the road, the darkest part

Into the narrow lanes, I can't stumble or stay put ... (17-18)

These lines bear an apocalyptic conflation of the middle of the day and darkness in a manner which recalls the opening phrase - "Darkness at the break of noon" - of Dylan's 1965 song "It's Alright, Ma (I'm only 
bleeding)." Both the first two lines of the last verse of "I and I" and the opening phrase of "It's Alright Ma" allude to an expression in Chapter 8 of the Old Testament Book of Amos, which concerns the Jewish conception of the final divine judgment on the Day of the Lord, the Day of Yahweh, when retribution against individuals is to be meted out, as Yahweh declares in Jeremiah: "I will utter my judgements against them ... who have forsaken me ... and worshipped the works of their own hands"' (1.16). What we hear in Amos is both a warning that Judgment on the Day of Yahweh will fall not on Israel's enemies alone and the apocalyptic prediction of darkness at noon which Dylan adopts:

it shall come to pass in that day, saith the Lord God, that I will cause the sun to go down at noon, and I will darken the earth in the clear day ... (8.9)

Dylan's words in the first two lines of the last verse of "I and I" compound the chosen and the willed ("still pushin' myself") with an unease at the paradoxical inevitability of the movement onwards into darkness (not "I won't stumble ..." but "I can't stumble or stay put"). It is as if the self is impelled towards an end which, while at one level sought, is at another level determined and feared. It is an enactment of the urgent relation between the mortal self and the awe-inspiring difference of the divine nature that is played out in the refrain to the song. The mortal self is driven towards a confrontation with an absolute that it recoils from in its inflexible, judgmental otherness.

Anxiety at the thought of judgment of the individual is evident again in Dylan's 1985 song "Dark Eyes." In the third verse of this song, worldly maneuverings are dismissed as nothing in the face of the fire of judgment:

They tell me to be discreet for all intended purposes

They tell me revenge is sweet and from where they stand I'm sure it is

But I feel nothing for their game where beauty goes unrecognized

All I feel is heat and flame and all I see are dark eyes

In "I and I" the unconditional justice of Mosaic law is described as having a "beautiful face" (11). The speaker of "Dark Eyes" is conscious of the same absolutist "beauty." The "dark eyes" themselves make the same pun as Dylan had made twenty years earlier, in "Like a Rolling 
Stone," on the homophone "eye," organ of sight, and "I," personal pronoun. ${ }^{3}$ The darkness of the "I"-s in "Dark Eyes" defines at once the ominous inscrutability of the principle of judgment to which the self is subject and the fallen nature of that self.

The tone of awe in the face of an unrelenting, unforgiving divine principle that can be heard in both "I and I" and "Dark Eyes" was intensified in a glorious performance Dylan gave of "I and I" in a concert in Washington on 7 July 1986. After the singing of the second refrain in this performance - conditioned by Dylan's tensely urgent voice, driven by the anxious compulsion of the music - the chorus starts singing "Oh, no! no!" This continues at the end of the subsequent refrains until, following the singing of the refrain one last time, the principal thing one hears is "Oh, no! no! no! ..." The repeated choric "no!"-s intensify the sense of dread at facing the thing that the words, Dylan's singing, and the music move inexorably towards. "[N]o man sees my face and lives." Like his white-face performance of "Isis" in Montreal on 4 December 1975, included in Renaldo and Clara, Dylan's Washington rendering of "I and I" is a spectacle of possession. It demonstrates the breathtaking increase in expressive range which he can bring, in performance, to the verbal richness of his song poems.

But Dylan didn't just hear his ancestors calling in the years after his Christian excursion of the late 1970s and early 1980s. The ancestors had always been calling. The first time we hear of them is at the very outset of Dylan's lyrical career. In "Long Time Gone," a song recorded in August 1962 (Gray 646), Dylan declared: "But I know I ain't no prophet / An' I ain't no prophet's son" (53-4). This is practically a quotation of the words of the Prophet Amos, as he describes his origin and background: "I was no prophet, neither was I a prophet's son" (7.14). At about the same time as he composed "Long Time Gone," Dylan wrote a song about final judgment called "I'd Hate to Be You on That Dreadful Day," and the disavowal, through Amos, of a prophetic stance in "Long Time Gone" succeeds only in emphasizing the extent to which his imagination is saturated in the visionary perspective that we find in the Book of Amos. Amos records the judgmental words of Yahweh as He castigates his people for empty observances:

Shall not the day of the Lord be darkness, and not light? ...

I hate, I despise your feast days ... (5.20-21) 
But let judgement run down as waters, and righteousness as a mighty stream. (5: 24)

The punishment of sinners on the Day of the Lord, when it comes, will be conducted with extreme prejudice:

Though they dig into hell, thence shall my hand take them ... (9:1-2)

... the Lord God of hosts is he that toucheth the land, and it shall melt ... and it shall rise up wholly like a flood; and shall be drowned, as by the flood of Egypt. (9.5)

Behold, the eyes of the Lord God are upon a sinful kingdom, and I will destroy it from off the face of the earth ... (9.8)

All the sinners of my people shall die by the sword ... (9.10)

As the 1960s advanced, Dylan frequently read the social and political turmoil of the times through the Biblical lens of an ultimate judgment that will fall upon a miscreant people. One of the most familiar examples is "A Hard Rain's A-Gonna Fall," released in 1963, only the second year of Dylan's recording career. "Hard Rain" may have been apposite to the paranoid atmosphere surrounding the Cuban missile crisis of October 1962, about the time the song was written, but its large imaginative scope, recalling the "rain" which falls when "the windows of heaven were opened" to destroy a corrupt world in Genesis $(7.4,11)$, is not narrowly topical. Waters of oblivion threaten, rather, an unregenerate America, a fallen promised land where dispossession and alienation reign:

Oh, what'll you do now, my blue-eyed son? ...

I'm a-goin' back out 'fore the rain starts a-fallin'

I'll walk to the depths of the deepest black forest

Where the people are many and their hands are all empty

Where the pellets of poison arc flooding their waters

Where the home in the valley meets the damp dirty prison

Where the executioner's face is always well hidden

Where hunger is ugly, where souls are forgotten ... $(42,44-50)$

Noah's flood, it is well known, rises repeatedly in Dylan's earlier, preChristian work from the 1960s and 1970s, noticeably in songs like 1964's "The Times They Are A-Changin"” or 1967's "Down in the Flood." Nor does the figure of deluge ever entirely recede from his lyrics - one of the most significant recent examples being "High Water," on 2001's Love 
and Theft (though in this song fire also appears indirectly through the reference in line 11 to Jane Eyre's Bertha Mason). The combination of deluge and fire reappears in songs from Dylan's 2006 Modern Times. The first line of the first song of Modern Times strikes the apocalyptic note that sounds right through the album: "Thunder on the mountain, and there's fires on the moon" ("Thunder on the Mountain"). Apocalyptic apprehension controls the ironic imagining of a woman dressed to kill in the second to last song on the album, "The Levee's Gonna Break":

Put on your cat clothes, mama, put on your evening dress

Few more years of hard work, then there'll be a thousand years of happiness... (32-33)

In the last two verses of the very last song poem on Modern Times, "Ain't Talkin'," there is yet another picture of the last things:

As I walked out in the mystic garden

On a hot summer day, a hot summer lawn

Excuse me, ma'am, I beg your pardon

There's no one here, the gardener is gone

Ain't talkin', just walkin'

Up the road, around the bend.

Heart burnin', still yearnin'

In the last outback at the world's end.

What is emphasized in these lines is, once more, the idea of an end that is unrelieved by the Christian dispensation. In John 19 and 20, when Mary Magdalene stands "in the garden" (19.41), near the sepulcher where the crucified Christ was lain but from which the body has disappeared, she sees a figure whom she supposes "to be the gardener" (20.15). Grieving, she asks the "gardener" if he knows where the dead Christ has been taken; only to have the gardener reveal that he is himself the transfigured, risen Christ. In the tenth verse of "Ain't Talkin"” we hear that "The suffering is unending / Every nook and cranny has its tears" (58-59). In John 20.15 the risen Christ questions why Mary Magdalene is weeping. In Dylan's song, however, there is no one to declare that there is no need for tears. The gardener is gone. There is no risen Christ and the desolation of the world's end, fraught with religious yearning, is bereft of religious hope.

In the 1970 s the deluge was alluded to not only in the words of Dylan's songs. Patrick Crotty notes that "a bid to affect the excitement of immi- 
nent catastrophe presumably underlay the title of the Before the Flood tour [in 1974], as its Rolling Thunder successor [in 1975-76]" (326). The 1976 collection of live performances from the Rolling Thunder tour was itself titled Hard Rain and, while it did not include a version of "A Hard Rain's A-Gonna Fall," it did have a version of the 1975 Blood on the Tracks song, "Shelter from the Storm," a work relevant in his context. On one important occasion, in Dylan's 1965 song "Desolation Row," a figure of a culture under sentence of watery death is juxtaposed with that of its extinction by fire in a way that combines allusion to the deluge in Genesis with the judgmental perspective of the Book of Revelation. Characters drawn from "Western literature, folklore and history" (Day 82) spend their time, in the third verse of the song, "expecting rain" (32). One of them, Ophelia, has her "eyes ... fixed upon / Noah's great rainbow" (4546); and, in the ninth verse, "Ezra Pound and T.S. Eliot" fight in the "captain's tower" as their ship sinks "Between the windows of the sea" (101$2,105)$. Neil Corcoran notes that the place name Desolation Row functions as "a metonym for the United States in 1965" (162). As such, all the scenarios detailed in the song are subject, as Michael Gray has put it, to the "evocation of impending catastrophe" (136), which opens the penultimate verse:

Praise be to Nero's Neptune

The Titanic sails at dawn (97-98)

Thus, modern American culture is pictured as a ship of fools about to suffer a catastrophic drowning. But what is particularly interesting is that in these lines America is at once the Babylon of Revelation. Because the emperor Nero was not only credited with having started the great fire of Rome in AD 64, he persecuted the early Christians viciously and he has traditionally been understood as one of the "heads" of the "beast" whose name was "blasphemy" in Revelation 13.1, 3.

The associations with punishment by water and by fire in this couplet from "Desolation Row" point to a fundamental connection between Dylan's earlier, pre-Christian lyrics and his later Christian and postChristian work. The representation of terminal situations in Dylan's earlier songs is frequently in terms of a deluge; just as the imaging of the same situation in his later work is often in terms of apocalyptic fire. But what is important is that Dylan's sense of imminent, absolute Judgment 
and of punishment meted out either by water or fire - sometimes by both - is the deepest and most consistent imaginative preoccupation of his lyrical career. It is a paradigm of his social and political songs. It is a pattern of his explorations of personal identity. It is an important dimension of his love songs (consider, to choose a single example, the apocalyptic rhetoric which saturates the account of a love relationship in the 1985 "When the Night Comes Falling from the Sky"). This judgmental and apocalyptic obsession in Dylan needs to be understood in a different way than in the postmodern terms which some critics, including myself, have used to interpret Dylan's imaginative frame of reference.

Dylan has always been famous for his seemingly endless changes in subject, stance, and perspective across his more than forty years of writing song poems. Endless apparent change and revisioning is one of the most compelling and exhilarating dimensions of his work. Bryan Cheyette describes one view of this phenomenon when he speaks of Dylan's "many conversions" as "a form of freewheeling self-reinvention, which makes everything heterodox and provisional" (222). In my 1988 study, Jokerman: Reading the Lyrics of Bob Dylan, I took what I called "the troupe of irregular and carnivalesque figures that processes through Dylan's work" as a token of Dylan's characteristic imaginative heterodoxy and provisionality (80). At the end of my book, speaking of "Jokerman," I saw a celebration of a kind of postmodern groundlessness in the song:

In "Jokerman" Dylan adopts the figure of the Joker to give emblematic shape to a vision of the bizarre, undecidable nature of human identity. Generating questions which it does not resolve, the lyric is presented to its audience in the form of a question or riddle. In its refusal to close lies its strength, its commitment to confront and challenge. And in that refusal it epitomises the most distinctive perspective of Dylan's lyrical career: a continually renewed scepticism regarding the possibility of attaining absolutely final positions ... (142)

I no longer agree with this reading of Dylan's imaginative orientation. I now view the consistent anticipation, in various guises, of final catastrophe, social and personal, as the matrix of Dylan's lyrical imagination. These invocations of Judgment are not secularized poetic images. They are manifestations of imaginative belief. The hearing of the ancestors in "Caribbean Wind" was only another expression of an imagination constituted in an Hebraic conviction of the inevitable and dread-inducing 
nature of divine judgment. Dylan's many changes are not to be read as an expression of groundlessness. Carnival is, always was, a deviation from and an exploration of possibilities outside - a fixed order. Dylan's varied carnival across so many of the phases of his lyrical career is a highly energized, immensely fertile version of this exploratory impulsc. But his carnivalesque exultation in a multiplicity of selves, his endless conversions, are the strategies of a mind creatively, sometimes desperately, seeking to negotiate, to refuse, to escape what it knows to be the inevitable. Dylan's Christian phase may be read as an attempt to escape a conviction of doom through the adoption of a God less inflexible than that of the Hebrew Bible. In this respect there would be, from a critical perspective, something of the carnival in the Christianity that Dylan attempted to escape into. In contradistinction to what I said in 1988, I would now read the immediately post-Christian song "Jokerman" as a deliberately negative carnivalization of Christianity itself, with its Christfigure cast pointedly as an unstable, unreliable and untrustworthy figure of carnival. In a comparable way, the vacuum of the mystery tramp's eyes in the 1965 "Like a Rolling Stone" may be seen to define less an exhilarating freedom than a disturbing void of being. It may actually feel and be very bad to have no direction home. It may be a symptom of an absurd irresponsibility. ${ }^{4}$

Interestingly, Dylan, again very early in his career, provided an autobiographical figure for the idea that his changes are motivated by a need to escape what is already known as a terminal situation. In "11 Outlined Epitaphs," printed as the sleeve notes to his 1964 album The Times They Are A-Changin', we hear of the small town, Hibbing, in which Dylan grew up, the son of second generation Jewish immigrants. As is well known, Hibbing is built on an iron ore range and in the 1920s the town itself was moved south so that a particularly rich vein of iron ore underneath the town could be mined. Parts of the old town, North Hibbing, remained, and in the second of "11 Outlined Epitaphs" Dylan tells us of the "legacy visions" afforded by his origins:

the town I grew up in is the one

4. My understanding, here, of the temporariness of Dylan's conversion to Christianity obviously differs from Bryan Cheyette's important reading of that conversion as constituting a fundamental break in Dylan's imaginative preoccupations. (See Cheyette 221-52). 


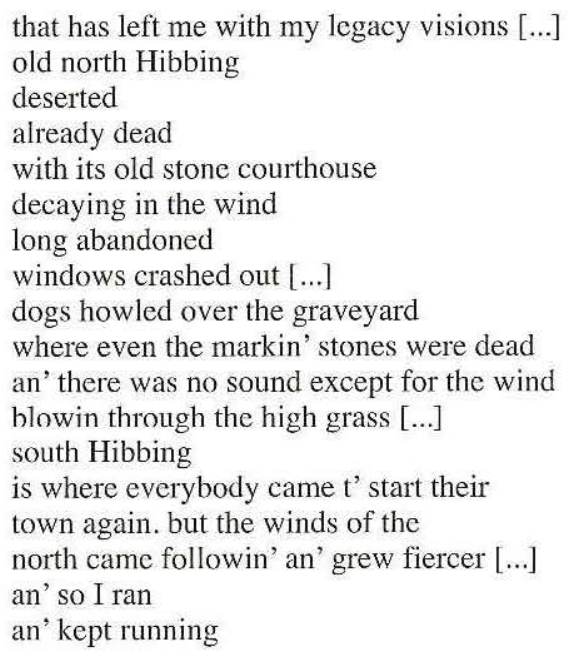

"[T] he winds of the / north came followin' an' grew fiercer." Like the wind that blows, exciting the furnace, in "Caribbean Wind." It is an apocalyptic wind which blows again in "Thunder on the Mountain" from Modern Times: "The sun keeps shinin' and the North Wind keeps picking up speed" (19). But the running in "11 Outlined Epitaphs" is not a running without a point of reference. It is a running away. The ground of the running is that wasted land, and since Dylan drew it in the early 1960s he has repeatedly returned, from the midst of multiple explorations of different selves, to express it. The legacy visions of a fiercely, apocalyptically desolate landscape anchor and authorize the unique authenticity, the non-provisionality, of the imagination that suffers the visions.

\section{References}

Byatt, A.S. "Introduction" to The Song of Solomon. Edinburgh: Canongate Pocket Classics, 1998.

Cheyette, Bryan. "On the 'D' Train: Bob Dylan's Conversions." "Do You, Mr Jones?" Bob Dylan with the Poets and Professors. Ed. Neil Corcoran. London: Chatto and Windus, 2002. 221-52.

Cohen, Scott. "Bob Dylan: Not Like a Rolling Stone Interview." Orig. in Spin (December 
1985). Rpt. in Younger than That Now: The Collected Interviews with Bob Dylan. Ed. James Whitfield Ellison. New York: Thunder's Mouth Press, 2004. 217-34.

Collins, John J. The Apocalyptic Imagination: An Introduction to the Jewish Matrix of Christianity. New York: Crossroad, 1984.

Corcoran, Neil, ed. "Do You, Mr Jones?" Bob Dylan with the Poets and Professors. London: Chatto and Windus, 2002.

Crotty, Patrick. "Bob Dylan's Last Words." "Do You, Mr Jones?" Bob Dylan with the Poets and Professors. Ed. Neil Corcoran. London: Chatto and Windus, 2002.307-33.

Day, Aidan. Jokerman: Reading the Lyrics of Bob Dylan. Oxford: Blackwell, 1988.

Ford, Mark. "Trust Yourself: Emerson and Dylan." "Do You, Mr Jones?" Bob Dylan with the Poets and Professors. Ed. Neil Corcoran. London: Chatto and Windus, 2002. 12742.

Gray, Michael. Song and Dance Man III: The Art of Bob Dylan. London: Cassell, 2000. 